Published in Gender, Embodiment, and the History of the Scholarly Persona: Incarnations and Contestations, ed. Kirsti Niskanen and Michael J. Barany (Cham: Palgrave Macmillan, 2021), 261-286, https://link.springer.com/chapter/10.1007/978-3-030-49606-7 10

\title{
The Whole Man: A Masculine Persona in German Historical Studies
}

Herman Paul

\section{Introduction}

To what extent did German historians in the nineteenth and early twentieth centuries aspire to be 'a whole man' (ein ganzer Mann)? ${ }^{1}$ Historians, not unlike philosophers and novelists, used the phrase on numerous occasions, as shorthand for a mode of masculinity that sought to reconcile demands of reason and emotion by combining astuteness, industry, and determination with imagination, love of country, and 'human warmth.' As Martina Kessel has argued, the wide spread of this 'whole man' rhetoric in the late nineteenth century can be interpreted as a sign of dissatisfaction with growing societal differentiation, including especially a drifting apart of the traditionally male territory of work and the female-gendered realm of domestic life. In this reading, der ganzer Mann such as propagated in nineteenth-century novels and moral advice literature appears as "a man of the world," able to integrate "the increasingly distinct spheres of work, family, private life and sociability.",

For many German historians, this was an attractive ideal. The Munich historian Karl Theodor Heigel (1842-1915), for instance, invoked it in many of his biographical essays, especially in praising scholars and artists whom he judged able to satisfy demands of reason and emotion alike. Yet what exactly was Heigel doing in advocating a whole man ideal? Did he give voice to an ideal of masculinity that was widely shared in his profession? Or did the ideal serve instead as a corrective to a growing dominance of historians socialized in institutional contexts (e.g. source editing projects like the Monumenta Historiae Germanica) that stimulated their rational capacities more than their emotional sensitivity?

In his fascinating recent study of masculine ideals and practices in German historical studies, Falko Schnicke argues that the whole man amounted to a "disciplinary persona" to which nineteenth-century historians were all expected to conform. ${ }^{3}$ Insofar as the whole man rhetoric conveyed a desire to avoid one-sidedness that comes with overspecialization or, in positive terms, a desire to live a well-balanced life, this is no doubt correct: no historian dared to advocate abandonment of political responsibilities or moral duties for the sake of full devotion to historical research. However, in presenting the whole man as a marker of the "male character of the discipline as a whole," Schnicke overlooks that der ganzer Mann primarily served as a contrastive ideal, invoked by historians who criticized or distanced themselves from alternative models of professional identity. ${ }^{4}$ Specifically, when Schnicke quotes the 1886 obituaries of Leopold von Ranke and Georg Waitz as evidence for the prevalence of the whole man ideal, he ignores that Waitz was widely perceived as embodying an antithetical model, given that both he and his students, intentionally or not, downplayed the importance of political commitment and aesthetic talent for historians committed to deepening historical knowledge. ${ }^{5}$

As I shall argue in this chapter, it was precisely the (perceived) growing dominance of Waitzean Fachmänner in late nineteenth-century German historical studies that led Heigel and 
others to admire ganze Männer. The whole man was invoked, not as a shared ideal, but with the aim of challenging a competing model: that of the Zunftgelehrte or 'guild scholar' who slavishly conformed to what his profession demanded from him, never transgressed the confines of his specialism, and seldom displayed any passion except appetite for work and excessive love of detail. Precisely to the extent that Zunftgelehrten failed to recognize both the political significance of historical scholarship and the importance of reaching non-specialist audiences with well-written books, Heigel felt a need to advocate the whole man as an alternative model of how to be a historian. The case of Heigel therefore draws attention to a plurality of scholarly personae that circulated among historians in Wilhelmine Germany. If scholarly personae are culturally sanctioned models of how to be a scholar, typically described in terms of virtues, skills, or competencies, then Heigel's juxtaposition of Fachmänner and ganze Männer shows that such personae did not exist in the singular. ${ }^{6}$ Multiple personae, often defined in contrast to each other, competed for hegemony within the historical profession.

In passing, I will note that much the same is true for the modes of masculinity implied in these competing scholarly personae. Drawing on what Kessel calls a polar gender model, Johann Gustav Droysen, Heinrich von Treitschke, and others insisted on the need for historians to excel in 'male' virtues traditionally associated with Prussia and Protestantism: courage, determination, and commitment to a public cause. Consequently, they perceived the Waitzean persona as lacking 'male strength' and 'firmness.' Heigel's whole man ideal, however, challenged such polarizing of male and female character traits. It tried to combine them by demanding historians to cultivate such traditionally female traits as empathy and sensitivity, in addition to Treitschkean resoluteness and 'warm-blooded' patriotism. What this suggests is that different personae could have different gender connotations. Although, by Heigel's lifetime, German historical studies was still an all-men's business, the kinds of masculinity embraced by German historians were more diverse than scholarship has so far acknowledged. ${ }^{7}$

\section{Spice nuts and marzipan}

Who was Karl Theodor Heigel? Although he was one of many German historians who had grown up with poetry and drama, Heigel was rather unique in being a theater director's son who had applied to an art academy, been rejected, and become a history professor instead (at his alma mater, the Ludwig Maximilian University of Munich, where he acquired a leading position next to Hermann Grauert and Sigmund Riezler). Heigel's presidency of the Bavarian Academy of Sciences, from 1904 to 1915, testified to his high standing in Bavarian academic life. ${ }^{8}$ His artistic inclinations had never left him, though. Heigel was a gifted speaker and a vivid stylist, who wrote a handful of books (including a well-received biography of Ludwig I of Bavaria), but greatly preferred the essay format. As Alfred Dove, himself a prolific essayist, once said: Heigel knew how to do research, but was at his best in his vignettes, portraits, essays, and sketches. ${ }^{9}$ Few of these pieces appeared in professional journals: most of them were solicited by papers like the Allgemeine Zeitung and subsequently collected in volumes of essays, almost a dozen of which appeared during Heigel's lifetime. ${ }^{10}$

Judging by these essays, the greatest praise that Heigel could bestow on a person was that he had been 'a whole man.' This was how he characterized, among others, the mineralogist and poet Franz von Kobell, the Bavarian cabinet secretary Friedrich von Ziegler, and the two men who had towered over German politics in the 1870s and 1880s: Emperor Wilhelm I and 
Chancellor Otto von Bismarck. In describing these men as "whole," "well-rounded," or "balanced," Heigel invoked a figure with outspoken masculine connotations. Over against a classic, polarized gender model that equated masculinity with reason and femininity with emotion, the 'whole man' represented a combination of these qualities. "Educated yet sensitive, energetic yet passionate and capable of empathy," the whole man was, in Heigel's words, endowed with qualities of "head and heart" alike, which enabled him to think like a statesman without lacking human warmth. ${ }^{11}$

Partly, this wholeness was achieved by cultivating social and cultural practices outside one's immediate sphere of work. In Ziegler, who Heigel said was as thoroughly acquainted with contemporary art as with the intricacies of Bavarian politics, as well as in Kobell, "a real artist and true scholar," Heigel admired an earnest commitment to Bildung. ${ }^{12}$ Yet equally important as broad cultural formation was a commitment to sociability, such as exhibited by Wilhelm von Giesebrecht, Heigel's teacher and predecessor at the University of Munich. Giesebrecht's adage, "Labour during day hours, guests at night," aptly conveyed the importance of balancing work with social activities. Drawing on personal memories, Heigel narrated how Giesebrecht had had the habit of buying Christmas presents for his students, spending Christmas Eve with them around a Christmas tree in his living room, and filling their pockets with spice nuts and marzipan before saying them goodbye. ${ }^{13}$

Even more important than Bildung and sociability, however, was the dispositional precondition for both: a well-rounded, evenly developed character, able to maintain a balance between the demands of reason and emotion. "Strong-minded and indefatigable active, yet receptive to inspiration [Begeisterung]," the ganzer Mann as Heigel envisioned him was neither a dispassionate rationalist nor a man ruled by his feelings. ${ }^{14} \mathrm{He}$ "abhors the sentimentality of unhardened hearts as much as rudeness of character, falsely admired as 'tranquility that comes with life experience." 15 For professionals working in contexts that stimulated their rational capacities more than their emotional sensitivity, this ideal of wholeness therefore served as a corrective. As Heigel observed about Ludwig von Bürkel, another high official at the Bavarian court: "Being a man of the world [Weltmännliches Wesen] does not seem compatible with warm-hearted friendship." Yet Bürkel, as formal and aloof as one would expect a Weltmann to be, had proven himself able of cordial friendships and true compassion with others, thereby challenging traditional masculine stereotypes in the all-male world of Bavarian high officialdom. ${ }^{16}$

Some of this may seem reminiscent of eighteenth-century ideals of balance and moderateness such as found among historians like Johann Georg Wiggers and Arnold Heeren. ${ }^{17}$ At least in one respect, however, Heigel's ideal distinguished itself from these older ones. For Heigel, receptiveness to inspiration was inseparable from an ability to hear the voice of duty when it called, to recognize the demands of the time (Forderung des Tages), and to acknowledge the priority of patriotism, especially at moments when the country was in need. ${ }^{18}$ Ganze Männer, therefore, included those "courageous strategists, quiet scholars, passionate poets, [and] far-seeing civil servants" who had prepared the path to Germany's unification and, after the outbreak of World War I, those students and professors who abandoned their regular duties to volunteer in the army. ${ }^{19}$ Without exception, Heigel's ganze Männer were warmblooded patriots, who treated others not merely on spice nuts and marzipan, but also, if needed, on bullets and bombs. 


\section{Heinrich von Treitschke}

When Heigel looked for such 'whole men' among his contemporaries in the German historical profession, it was Heinrich von Treitschke whom he regarded as the highest embodiment of this ideal. On various occasions, but most notably given in a lecture at the University of Munich, two years after Treitschke's death, Heigel portrayed the Berlin historian as an earnest man, living by the courage of his convictions, staunchly defending his views in classroom and parliament alike, yet able to turn into a cheerful conversationalist as soon as glasses appeared on the table. ${ }^{20}$ Despite all quarrels and criticism, Treitschke's life and work had been harmonious, as the man had managed to combine "the two highest tasks of the historian, the artistic and the scholarly," most notably in his Deutsche Geschichte im neunzehnten Jahrhundert (5 vols., 1879-1894). ${ }^{21}$ On top of that, Treitschke had been a true patriot, "German in every fiber" of his being, who sang his country's praise occasionally a bit too loud, yet was clearly committed to serving the national cause, while showing an admirable talent for discerning what kind of historical studies the German people needed. ${ }^{22}$ So, for Heigel, Treitschke came close to embodying the ganzer Mann ideal - "the rolling-into-one of "the scientist, the artist and the warrior." 23

Unmistakably, for Heigel, the historian as a whole man sharply contrasted with other kinds of historians, including especially the narrow specialist. In his Munich lecture, Heigel depicted Treitschke as the antithesis of a type known as Zunftgelehrte - a historian who slavishly conforms to what his guild demands from him, never transgresses the confines of his specialism, and seldom displays any passion except appetite for work and excessive love of detail. ${ }^{24}$ In Johann Gottfried Herder's classic description, approvingly quoted by Heigel, such Zunftgelehrten are like "apothecaries of old fallen autumn leaves who do not see the forest bursting into bud and leaf." 25 They may know everything about late medieval charters, but treat the Holy Roman Empire as if it were as dead as the Babylonian or Macedonian past, without realizing that its trees begin to sprout out green leaves again - a metaphoric reference to the Empire of $1871 .{ }^{26}$ Zunftgelehrten, in other words, lack the 'wholeness' that Heigel appreciated in Treitschke because of their failure to recognize the political significance of their work as well as their inability to write anything except dry scholarly prose.

In Heigel's mouth, then, Zunftgelehrten was as derogatory a term as Urkundionen in Jacob Burckhardt's vocabulary (referring to a "type of philologists and historical researchers," prevalent in circles of the Monumenta Germaniae Historica, "who consider themselves superior to everyone if they have found out that Emperor Conrad II went to the toilet at Goslar on May 7, 1030"). ${ }^{27}$ Indeed, by ironically dismissing Zunftgelehrten, Heigel joined a chorus of voices complaining about virtues of accuracy and precision that were degenerating into vices of pettiness and narrow-mindedness, especially among historians in contexts like the $M G H$. As Droysen had famously thundered in a letter to Wilhelm Arendt: "We in Germany have, through the Rankean school and the Pertzians [i.e., the young historians employed by Georg Heinrich Pertz in the $M G H]$, got grumpily bogged down in so-called criticism, whose entire enterprise consists of deciding whether one poor devil of a chronicler has transcribed something from another."28

In his talk on Treitschke, Heigel specified the target of his criticism by paraphrasing yet another critic of narrow-minded professionalism, the essayist Karl Hillebrand, who already in 
the 1870 s had mocked the pedantry of young history graduates who seemed to know exactly what counted as professional and what did not: "If Thucydides appeared in public today, a private lecturer from Leipzig or Göttingen would know well how to expose, in one or another literary periodical, the lack of method of the unfortunate historian who is not a product of Ranke's or Waitz's seminar." 29 Tellingly, in his paraphrase, Heigel omitted Ranke's name - he had too much respect for the Berlin historian - so that Waitz-style professionalism became the sole target of his criticism. ${ }^{30}$ This was unsurprising: philological virtues ('criticism,' 'precision,' 'penetration') had been cultivated nowhere as sternly as in Waitz's historical exercises. $^{31}$ Waitz, moreover, had regarded literary style as an overpriced good. He had famously claimed that historians ought to value research (Forschung) over writing (Darstellung). ${ }^{32}$ Also, over the course of his career, Waitz had distinguished ever sharper between scholarship and politics, which had made him an almost perfect antitype of Treitschke, who did not hesitate to admit that the patriot in him was a thousand times starker than the professor. ${ }^{33}$ As Ernst Bernheim observed, some of Waitz's students, plus royaliste que le roi, managed to show even more contempt for artistic and political aspirations than Waitz himself had done, which in turn made them easy targets for scorn from historians identifying with Treitschke or Heinrich von Sybel. ${ }^{34}$

So when Heigel exhorted the students in his audience to read Treitschke's Deutsche Geschichte, "the most splendid achievement of German historical writing," he hoped these volumes would show them that historical research was not incompatible with aesthetic aspiration or patriotic feeling: "Wissenschaftlichkeit does not exclude a warm heartbeat." ${ }^{35}$ In a more critical vein, Heigel held up the example of Treitschke to challenge a mode of historical scholarship that "inclines towards Alexandrianism, only serving itself." 36 Like Treitschke himself, who had ridiculed all "well-educated seminar plants," or Dove, who had mocked "the narrow philological school of seminars à la Waitz,"37 Heigel sought to delegitimize a type of historian that was well-versed in Latin palaeography, but ignorant or even indifferent about art and politics. The whole man, in other words, served as an antitype to the Zunftgelehrte, or as an anti-ascetic model that aimed to correct the one-sidedness of a Waitzean catalogue of virtues.

\section{Scholarly personae}

Crucially, this strategy did not imply total identification: Heigel reserved the right to be critical of Treitschke. As a Bavarian, he told his audience, "I could never befriend myself with Treitschke's political confession of faith." ${ }^{.38}$ Neither did his praise imply that he admired Treitschke's "too ornate rhetoric" or that he dreamt of a political career like Treitschke's. ${ }^{39}$ Likewise, Heigel's stated aversion to historians of the sort bred in Waitz's exercises did not amount to an attack on his colleague Hermann Grauert, who had been a product of these Übungen, or to a belittling of the auxiliary sciences such as taught in Munich. ${ }^{40}$ The book series that Heigel edited with Grauert included volumes on medieval constitutional history that could have been written under Waitz's supervision. ${ }^{41}$ Also, several Munich dissertations dwelt at length on such highly specialized issues as the authorship of the Confutatio primatus papae (a fifteenth-century antipapist treatise). ${ }^{42}$

Heigel's juxtaposition of Zunftgelehrten and ganze Männer must therefore not be misunderstood as a contrast between Treitschke and Waitz as individuals. At a more generic level, Heigel contrasted two types of historians, characterized by narrow devotion to the pursuit 
of historical knowledge and a fortunate cross-fertilization of scholarly, artistic, and political aspirations, respectively. In preferring the latter over the former, Heigel's point was not that Treitschke himself could serve as a model for imitation. The model in question was rather an ideal-type in Max Weber's sense of the word: an abstract concept, which never corresponds exactly to a historical case, but offers a deliberately "one-sided accentuation of one or more points of view," in relation to which real historical cases can be positioned. ${ }^{43}$ Treitschke came close to embodying Heigel's whole man ideal, just as Waitz came close to personifying the Zunftgelehrte. Strictly speaking, however, both Zunftgelehrten and ganze Männer were idealtypes, which could serve as convenient reference points for Heigel and his audience precisely to the extent that they offered schematic, one-sided descriptions of historiographical virtues and vices.

The virtue at stake in Heigel's juxtaposition of Zunftgelehrten and ganze Männer was a notorious one: 'objectivity.' 44 Interestingly, Heigel did not simply claim that objectivity was important to the former and irrelevant to the latter. The issue rather was what the virtue in question meant and what kind of objectivity historians should try to practice. Did objectivity amount to an "abstraction from our individuality" that would enable historians to interpret "the facts of history" without preconceived ideas (voraussetzungslos)? In that case, objectivity required a renunciation of all the "influences of our natural tendencies" that interfere with the acquisition of knowledge. ${ }^{45}$ Then objectivity amounted to an ascetic repression of passions and preferences such as often attributed to Ranke ("I wish I could as it were extinguish myself") and classically described by Ranke's older contemporary, Wilhelm Wachsmuth: "Robbed of all bonds of nationality, which might impede or impair the telling of truth, all temptations and views of a party or stand, [and] all religious bias, free from prejudices and affections except those for truth and virtue, [and free] from passions (sine ira et studio) . ." "46 This was the kind of objectivity that Droysen had denounced as "eunuch-like," in the sense of lacking "proud masculinity," and what Treitschke had condemned as the "bloodless objectivity" of historians unwilling or unable to put their hearts into their work. ${ }^{47}$

Following Treitschke, however, Heigel could envision a different kind of objectivity: one that made demands on head and heart alike. As Heigel quoted from a letter received from Treitschke in 1883: "I believe that historical objectivity consists in treating as large what is large and as small what is small." 48 On another occasion, Treitschke had defined true objectivity as "comprehension of the unlimited right of the personality." 49 Objective in this definition were those historians who acknowledged the importance of human agency, the great power of great men in particular ("It is men who make history"). ${ }^{50}$ Notably, this kind of objectivity did not require historians to suppress their feelings of admiration or contempt for historical agents, but encouraged them to express those value judgments, partly to recognize true greatness (or the lack thereof) among historical agents, partly also to demonstrate their own strength of character. Would any "German man" - Heigel's description of Treitschke - remain silent if his country's honor was assailed ${ }^{51}$ On the one hand, then, Heigel associated objectivity with 'doing justice' and with 'recognizing' someone's greatness, merits, or success. ${ }^{52}$ On the other, he emphasized that objectivity, rightly understood, was well compatible with patriotic feeling. As he stated shortly after his lecture on Treitschke: "[The historian] will always have to write cum studio and often cum ira." ${ }^{.53}$ 
Heigel's talk in Munich, then, was an exercise in drawing schematic contrasts, not for the sake of pinpointing Treitschke's or Waitz's position in German historical studies, but with the aim of propagating an anti-ascetic conception of the historian's task, consistent with an ideal of well-rounded masculinity. Although Heigel's ideal-typical contrast between ganze Männer and Zunftgelehrten emphasized the distinctiveness of Treitschke's achievements in a profession largely populated by narrow-minded specialists, the individual named Treitschke did not coincide with the type he represented. Close as he had come to embodying Heigel's ganzer Mann ideal, Treitschke had failed to meet his aesthetic standards. So, for Heigel, Treitschke deserved posthumous praise in so far as he had approached the ideal-type; not the other way around. Negatively, this implied that among German historians, the ganzer Mann was still an ideal awaiting full realization. Positively, however, it meant that others, too, could be honored for approximating the ideal - Ludwig Häusser and Sybel, for instance, in both of whom Heigel detected a felicitous pairing of "statesman-like insight" with "the quiet spirit of a researcher." 54 Consequently, Heigel's aim in juxtaposing Waitz and Treitschke was not to highlight individual differences, but to draw attention to two different models of how to be a historian, characterized by cold and warm-blooded objectivity, respectively.

Following Lorraine Daston and H. Otto Sibum, historians of the humanities have come to denote such models as 'scholarly personae. ${ }^{55}$ Part of what makes this concept attractive is that it draws attention to the demands that scholarly work makes upon the self. Historians employed by associations like the Hansische Geschichtsverein were often months away from home to collect and transcribe medieval sources in foreign archives (with only a quick chocolate bar for lunch, as Dietrich Schäfer remembered: no precious research time could be wasted on lunch breaks). ${ }^{56}$ These environments and job expectations made rather different demands on the historian's abilities than the University of Heidelberg, where in 1874 the newly appointed Bernhard Erdmannsdörffer faced the challenge of having to continue Häusser's and Treitschke's tradition of spectacular lecturing. ${ }^{57}$ 'Scholarly personae' is a technical term for the distinct catalogues of virtues, skills, or competencies characteristic of such models of how to be a historian. Given that the abilities that scholars deemed relevant for their work not only differed across institutional contexts, but also often changed considerably over time, scholarly personae are a promising prism for comparative, transdisciplinary lines of inquiry. ${ }^{58}$

Although the concept of 'personae' is relatively new - no nineteenth-century historian ever spoke about scholarly personae - it is worth emphasizing that the models denoted by it already existed in Heigel's own time. Nineteenth-century historians even engaged in fierce debate over such models, which they typically named after high-profile figures (Ranke, Sybel, Waitz, Johannes Janssen) whom they perceived as embodying certain virtues or vices more than others. Thus, George P. Gooch's 1913 verdict that "Ranke was the most objective, Treitschke . . . the most subjective of German historians" echoed late nineteenth-century commonplace distinctions between 'objective' historians following Ranke's footsteps and 'subjective' historians resembling Treitschke. ${ }^{59}$ Max Lenz and Martin Philippson are but two examples of historians who distinguished as schematically as Heigel between Treitschke-style 'subjectivism' and Ranke-style 'impartiality. ${ }^{60}$ This implies that there is no need for historians of the humanities to impose their own concepts of scholarly personae upon the past. They can fruitfully examine how nineteenth-century scholars themselves mapped their fields with help 
of clearly delineated models of virtue and tried to steer a course between, stay away from, or identify with one or more of these personae. ${ }^{61}$

\section{Modes of masculinity}

While these personae have so far been analyzed in terms of virtues and skills, hardly any attention has been paid to their gender connotations. There is an emerging body of literature on how scholars' 'self-fashioning' or 'presentation of self' - the voices they adopted, the clothes they wore, the beards they grew - conformed to, or challenged, culturally sanctioned standards for male and female conduct in public. ${ }^{62}$ Also, following Bonnie G. Smith, Falko Schnicke has done important work in showing to what extent nineteenth-century German historical studies were permeated with masculine values, as evidenced not only by stylized self-presentations (letters, photos, portraits), but also by the social codes regulating male exchange in educational settings (lectures, seminars, historische Übungen). ${ }^{63}$ Nonetheless, no one has tried so far to explain why Treitschke-style 'subjectivism' was experienced as more masculine than Rankestyle 'objectivity' or why Friedrich Christoph Schlosser, the man who lent his name to the persona of a 'moralist' historian, was still posthumously perceived as 'a male spirit' in comparison to the 'female one' associated with Ranke. ${ }^{64}$ Where did these different gender connotations come from?

The case of Heigel's whole man ideal allows for two observations. First, whereas the verdicts just quoted all relied on a polar gender model that presented sensibility and imagination as typically female and intelligence and judgment as characteristically male, der ganzer Mann challenged this dichotomy by requiring men to cultivate reason and emotion alike. In the realm of historical studies, this amounted to a rehabilitation of character traits traditionally associated with female history writing, such as Empfindsamkeit (sensibility). ${ }^{65}$ From Treitschke's perspective, Heigel's whole man was therefore less traditionally masculine than the persona he himself sought to embody. As long as intuition, empathy, and kindness were gendered as female, Heigel's admiration for well-rounded personalities that could just as easily paint a tender biographical portrait as summon their students to obey the voice of duty when the country was in need appeared as a curious mixture of male and female traits. ${ }^{66}$

Secondly, Heigel's example shows that models of masculinity were not only connected to scholarly personae, but also embedded in political and religious geographies. In Treitschke's understanding of things, Protestantism and Northern Germany (Prussia) were embodiments of masculine courage and determination, especially if compared to their feminine others: the Catholic Church and Southern Germany (Bavaria). ${ }^{67}$ Writing from Munich, and selfconsciously identifying as Bavarian, Heigel therefore faced the charge of having too feminine a background to stand on equal footing with Protestant historians from Prussian descent - just as Catholic historians throughout the German Empire had to counter the suspicion that they were incapable of 'Protestant' impartiality. ${ }^{68}$ Heigel's appropriation of the ganzer Mann ideal may therefore well have had an element of self-defense. It allowed him to highlight the masculinity of his favorite persona, even if this masculinity was of a different, less hegemonic kind than the one advocated by his Prussian colleagues.

\section{Epilogue}


To what extent, finally, these models were tied to specific moments in German history became apparent after Heigel's death in 1915. In their obituaries, Heigel's students almost unanimously argued that their teacher had embodied the very same qualities that he had admired in others. Heigel had been an artist and a scholar rolled into one, a 'man of fullness' (Mann der Gesamtheit), made 'of a single mold' (aus einem Gusse), or, in short, a whole man himself. ${ }^{69}$ As such, Heigel had been able to integrate art and scholarship in a harmoniously manner - a theme that ran throughout the obituaries. ${ }^{70}$ Yet precisely for this reason, Wilhelm Hausenstein argued, Heigel had also been a man of yesterday, even one of "before yesterday" - belonging to an age in which it had still been possible to be a man of learning and a man of letters simultaneously. ${ }^{71}$

Part of what gave the whole man ideal a distinctively nineteenth-century touch was, of course, the First World War. Back in 1911, Heigel himself had already pointed to a periodical need for 'virtues of war' - will-power, robustness, persistence, and fidelity to one's duties that were not exactly identical to the 'virtues of peace' practiced by Wilhelm von Giesebrecht on Christmas Eve. ${ }^{72}$ Another factor challenging the whole man ideal was the entrance of women into the historical profession. Just a few years after Heigel's death, the first female student would obtain a university teaching qualification (Habilitation) from the University of Munich - a clear sign that the days of all-male scholarly sociability were numbered. ${ }^{73}$ Most importantly, however, the professional identities of historians, journalists, and writers had been subject to processes of ongoing differentiation, partly through the growth of the historical profession and increasing habits of specialization among its members, partly also through 'professionalization' of German newspaper journalism. ${ }^{74}$

Against this background, Heigel could be interpreted as embodying a type of historian that was no longer available to his students - just as Alfred Dove had seemed as a voice from the past in continuing, until his death in 1916, the habit of preferring finely crafted essays over deftly footnoted monographs. ${ }^{75}$ Heigel had wanted to be a whole man in an age that saw the rise to prominence of a new scholarly persona, the Waitzean Fachmann, but been unable to reverse the trend, despite all inspiration that he had provided to his students. In the melancholic words of perhaps his most talented student, the Bavarian archivist and future Munich professor Ivo Striedinger: "The peculiar mixture of heart and mind that characterized him has once existed, but will not return..."

\section{References}

\section{Primary sources (unpublished)}

Berlin-Brandenburg Academy of Sciences and Humanities, Max Lenz papers, inv. no. 8, "Geschichte der deutschen Geschichtschreibung" (1901), transcript by Martin Hass.

\section{Primary sources (published)}

Albert, P. Matthias Döring, ein deutscher Minorit des 15. Jahrhunderts. Stuttgart:

Süddeutsche Verlagsbuchhandlung, 1892.

Bailleu, Paul. "Heinrich von Treitschke." Deutsche Rundschau 89 (1896): 41-76, 237-271. 
Bernheim, Ernst. Lehrbuch der historischen Methode: Mit Nachweis der wichtigsten Quellen und Hülfsmittel zum Studium der Geschichte. Leipzig: Duncker \& Humblot, 1889.

Burckhardt, Jacob. Briefe, edited by Max Burckhardt. vol. 3. Basel: Benno Schwabe \& Co., 1955.

Claar, Maximilian. Die Entwicklung der venetianischen Verfassung von der Einsetzung bis zur Schliessung des grossen Rates (1172-1297). Munich: H. Lüneburg, 1895.

Dove, Alfred. “Aus der Münchener historischen Werkstatt.” Beilage zur Allgemeinen Zeitung (February 10, 1900): 1-3.

Dove, Alfred ed. Gustav Freytag und Heinrich von Treitschke im Briefwechsel. Leipzig: S. Hirzel, 1900.

Dove, Alfred. Ausgewählte Briefe, edited by Oswald Dammann. Munich: F. Bruckmann, 1925.

Droysen, Johann Gustav. Historik (1857), edited by Peter Leyh, vol. 1. Stuttgart: FrommannHolzboog, 1977.

Droysen, Johann Gustav. Briefwechsel, edited by Rudolf Hübner, vol. 2. Osnabrück: BiblioVerlag, 1929.

D[üfel], F[riedrich]. “Karl Theodor von Heigel †,” Westermanns Monatshefte 118 (1915): 425-426.

Gooch, G. P. History and Historians in the Nineteenth Century. London: Longmans, Green, and Co., 1913.

Gothein, Eberhard. "Bernhard Erdmannsdörffer †: Ein Gedenkwort." Preußische Jahrbücher 104 (1901): 15-22.

Hausenstein, Wilhelm. “Karl Theodor von Heigel.” Das Forum 2 (1915): 44-48.

Heigel, Karl Theodor. Der österreichische Erbfolgestreit und die Kaiserwahl Karls VII. Nördlingen: C. H. Beck, 1877.

Heigel, [Karl Theodor]. "Ueber die Memoiren des bayerischen Ministers Grafen von Montgelas." Sitzungsberichte der philosophisch-philologischen und historischen Klasse der k. b. Akademie der Wissenschaften zu München (1885): 424-442.

Heigel, K. Th. "Ludwig I. von Bayern als Freund der Geschichte: Zum Centenarium seines Geburtstags.” Beilage zur Allgemeinen Zeitung (1886): 3449-3451, 3465-3467.

Heigel, Karl Theodor. "Wilhelm von Giesebrecht" (1889) in Heigel, Essays aus neuerer Geschichte, 313-325. Munich: C. C. Buchner, 1892.

Heigel, Karl Theodor. "Franz von Kobell" (1891) in Heigel, Essays aus neuerer Geschichte, 326-347. Munich: C. C. Buchner, 1892.

Heigel, Karl Theodor von. "Die Verlegung der Ludwigs-Maximilians-Universität nach München im Jahre 1826" (1897) in Heigel, Neue geschichtliche Essays, 21-50. Munich: C. H. Beck, 1902.

Heigel, Karl Theodor von. "Festrede zum Gedächtnis Kaiser Wilhelm I" (1897) in Heigel, Neue geschichtliche Essays, 306-331. Munich: C. H. Beck, 1902.

Heigel, Karl Theodor von. "Friedrich von Ziegler" (1897) in Heigel, Biographische und kulturgeschichtliche Essays, 290-297. Berlin: Allgemeiner Verein für deutsche Literatur, 1906.

Heigel, K. Th. Deutsche Geschichte vom Tode Friedrich d. Gr. bis zur Auflösung des alten Reiches. vol. 1. Stuttgart: J. G. Cotta, 1899.

[Heigel, Karl Theodor]. "Ludwig von Buerkel." Allgemeine Zeitung (July 24, 1903): 1-2.

Heigel, Karl Theodor von. "Einheitsstaat oder Bundesstaat?" (1911) in Heigel, Deutsche Reden, 1-21. Munich: C. H. Beck, 1916.

[Heigel, Karl Theodor von]. "Karl Theodor von Heigel” in Geistiges und künstlerisches München in Selbstbiographien, edited by W. Zils, 151-156. Munich: Max Kellerer, 1913. 
Heigel, Karl Theodor. “An die akademische Jugend!” Süddeutsche Monatshefte 11 (1914): 776-779.

Heigel, K. Th. von. Krieg und Wissenschaft: Rede gehalten in der öffentliche Sitzung der K. Akademie der Wissenschaften am 14. November 1914. Munich: Verlag der K. B. Akademie der Wissenschaften, 1914.

Heigel, Karl Theodor von. Zu Schillers Gedächtnis: Rede in der öffentlichen Sitzung der K. B. Akademie der Wissenschaften am 15. März 1905. Munich: K. B Akademie der Wissenschaften, 1905.

[Herder, Johann Gottfried]. "Philosophie und Schwärmerei, zwo Schwestern." Der Teutsche Merkur (1776):, no. 4, 138-149.

Hillebrand, Karl. "Ueber historisches Wissen und historischen Sinn" (1874) in Hillebrand, Zeiten, Völker und Menschen vol. 2, 311-333. Berlin: Robert Oppenheim, 1875.

Jacoby, Günther. "Herder as Faust." The Open Court 27 (1913): 98-119.

Jansen, Max. Die Herzogsgewalt der Erzbischöfe von Köln in Westfalen seit dem Jahre 1180 bis zum Ausgange des 14. Jahrhunderts: Eine Verfassungsgeschichtliche Studie. Munich: H. Lüneburg, 1895.

Joachimsen, Paul. "Karl Theodor Heigel †." Vergangenheit und Gegenwart 5 (1915): 207.

Joachimsohn, Paul. Gregor Heimburg. Bamberg: C. C. Buchner, 1891.

König, Erich. "Karl Theodor von Heigel †." Historisches Jahrbuch 36 (1915): 476-479.

Kruse, Heinrich von. Moritz von Sachsen: Trauerspiel in fünf Aufzügen. Leipzig: S. Hirzel, 1872.

[Lindau, Paul]. "Das literarische Parlament," Der Salon für Literatur, Kunst und Gesellschaft (1877): 226-230.

Marcks, E. "Karl Theodor von Heigel." Jahrbuch der Königlich Bayerischen Akademie der Wissenschaften 1916, 149-158. Munich: Verlag der k. b. Akademie der Wissenschaften, 1916.

[Müller, Karl Alexander von]. "Karl Theodor von Heigel.” Süddeutsche Monatshefte 12 (1915): 558-560.

Philippson, M. "Henri de Treitschke." Revue Historique 61 (1896): 349-353.

Ranke, Leopold. Englische Geschichte vornehmlich im sechszehnten und siebzehnten Jahrhundert. vol. 2. Berlin: Duncker \& Humblot, 1860.

Schäfer, Dietrich. Mein Leben. Berlin: K. F. Koehler, 1926.

Schorn-Schütte, Luise, and Ogrin, Mircea eds. "Über das eigentliche Arbeitsgebiet der Geschichte”: Der Briefwechsel zwischen Karl Lamprecht und Ernst Bernheim sowie zwischen Karl Lamprecht und Henri Pirenne 1878-1915. Cologne: Böhlau, 2017.

Sommerfeldt, Gustav. "Der Geschichtsforscher Karl Theodor von Heigel.” Mitteilungen des Vereines für Geschichte der Deutschen in Böhmen 54 (1915): 137-141.

Striedinger, Ivo. "Karl Theodor Heigel," in Heigel, Deutsche Reden, ix-xx. Munich: C. H. Beck, 1916.

Treitschke, Heinrich von. "F. C. Dahlmann." in Treitschke, Historische und politische Aufsätze vornehmlich zur neuesten deutschen Geschichte, 2nd ed, 359-445. Leipzig: S. Hirzel, 1865.

Treitschke, Heinrich von. Deutsche Geschichte im neunzehnten Jahrhundert. vol. 1. Leipzig: S. Hirzel, 1879.

Treitschke, Heinrich von. Deutsche Geschichte im neunzehnten Jahrhundert. vol. 2. Leipzig: S. Hirzel, 1882.

Treitschke, Heinrich von. Politik: Vorlesungen gehalten an der Universität zu Berlin. Edited by Max Cornicelius, vol. 1. Leipzig: S. Hirzel, 1897.

Treitschke, Heinrich von. Heinrich von Treitschkes Briefe, edited by Max Cornicelius, vol. 2. Leipzig: S. Hirzel, 1913. 
Treitschke, Heinrich von. Heinrich von Treitschkes Briefe, edited by Max Cornicelius, vol. 3. Leipzig: S. Hirzel, 1920.

Wachsmuth, W. Entwurf einer Theorie der Geschichte. Halle: Hemmerde und Schwetschke, 1820.

Waitz, Georg. "Falsche Richtungen: Schreiben an den Herausgeber." Historische Zeitschrift 1 (1859): 17-28.

Waitz, G. Die historischen Übungen zu Göttingen: Glückwunschschreiben an Leopold von Ranke zum Tage der Feier seines fünfzigjährigen Doctorjubiläums, 20. Februar 1867. Göttingen: W. Fr. Kästner, 1867.

Wolfram, Ludwig. "Zur Erinnerung an Karl Theodor von Heigel." Deutsche Geschichtsblätter 16 (1915): 135-146.

\section{Secondary literature}

Blanke, Horst Walter. "Historiker als Beruf: Die Herausbildung des Karrieremusters 'Geschichtswissenschaftler' an den deutschen Universitäten von der Aufklärung bis zum klassischen Historismus." in Bildung, Staat, Gesellschaft im 19. Jahrhundert: Mobilisierung und Disziplinierung, edited by Karl-Ernst Jeismann, 343-360. Stuttgart: Franz Steiner, 1989.

Bosch, Mineke. "Persona and the Performance of Identity: Parallel Developments in the Biographical Historiography of Science and Gender, and the Related Uses of Self Narrative." L'Homme 24, no. 2 (2013): 11-22.

Bosch, Mineke. "Scholarly Personae and Twentieth-Century Historians: Explorations of a Concept." Low Countries Historical Review 131, no. 4 (2016): 33-54.

Brechenmacher, Thomas. "Wieviel Gegenwart verträgt historisches Urteilen? Die Kontroverse zwischen Heinrich von Sybel und Julius Ficker über die Bewertung der Kaiserpolitik des Mittelalters (1859-1862)" in Historische Debatten und Kontroversen im 19. und 20. Jahrhundert, edited by Jürgen Elvert and Susanne Krauß, 34-54. Wiesbaden: Franz Steiner, 2003.

Daston, Lorraine, "Objectivity and Impartiality: Epistemic Virtues in the Humanities" in The Making of the Humanities, edited by Rens Bod, Jaap Maat, and Thijs Weststeijn, vol. 3, 27-41. Amsterdam: Amsterdam University Press, 2014.

Daston, Lorraine, and Sibum, H. Otto. "Introduction: Scientific Personae and Their Histories." Science in Context 16 (2003): 1-8.

Dickerhof-Fröhlich, Hedwig. Das historische Studium an der Universität München im 19. Jahrhundert: Vom Bildungsfach zum Berufsstudium. Munich: Minerva, 1979.

Dongen, Jeroen van, and Paul, Herman. "Introduction: Epistemic Virtues in the Sciences and the Humanities" in Epistemic Virtues in the Sciences and the Humanities, edited by Jeroen van Dongen and Herman Paul, 1-10. Cham: Springer, 2017.

Dotterweich, Volker. Heinrich von Sybel: Geschichtswissenschaft in politischer Absicht (1817-1861). Göttingen: Vandenhoeck \& Ruprecht, 1978.

Epple, Angelika. Empfindsame Geschichtsschreibung: Eine Geschlechtergeschichte der Historiographie zwischen Aufklärung und Historismus. Cologne: Böhlau, 2003.

Eskildsen, Kasper Risbjerg. "Private Übungen und verkörpertes Wissen: Zur Unterrichtspraxis der Geschichtswissenschaft im neunzehnten Jahrhundert" in Akademische Wissenskulturen: Praktiken des Lehrens und Forschens vom Mittelalter bis zur Moderne, edited by Martin Kintzinger and Sita Steckel, 143-161. Basel: Schwabe, 2015.

Gerhards, Thomas. Heinrich von Treitschke: Wirkung und Wahrnehmung eines Historikers im 19. und 20. Jahrhundert. Paderborn: Ferdinand Schöningh, 2013. 
Griffin, Ben. "Hegemonic Masculinity as a Historical Problem." Gender and History 30 (2018): 377-400.

Hausen, Karin. "Family and Role-Division: The Polarisation of Sexual Stereotypes in the Nineteenth Century: An Aspect of the Dissociation of Work and Family Life" in The German Family: Essays on the Social History of the Family in Nineteenth-and TwentiethCentury Germany, edited by Richard J. Evans and W. R. Lee, 51-83. London: Croom Helm, 1981.

Henz, Günter Johannes. Leopold von Ranke in Geschichtsdenken und Forschung, vol. 1. Berlin: Duncker \& Humblot, 2014.

Kessel, Martina. “The 'Whole Man': The Longing for a Masculine World in NineteenthCentury Germany." Gender and History 15 (2003): 1-31.

Krill, Hans-Heinz. Die Rankerenaissance: Max Lenz und Erich Marcks: Ein Beitrag zum historisch-politischen Denken in Deutschland, 1880-1935. Berlin: Walter de Gruyter, 1962.

Meister, Klaus. "Thucydides in Nineteenth-Century Germany" in A Handbook to the Reception of Thucydides, edited by Christine Lee and Neville Morley, 197-217. Chichester: Wiley-Blackwell, 2015.

Messerschmidt, James W. "Multiple Masculinities" in Handbook of the Sociology of Gender, edited by Barbara J. Risman, Carissa M. Froyum, and William J. Scarborough, 2nd ed, 143-153. Cham: Springer, 2018.

Mütter, Bernd. Die Geschichtswissenschaft in Münster zwischen Aufklärung und Historismus unter besonderer Berücksichtigung der historischen Disziplin an der Münsterschen Hochschule. Munster: Aschendorff, 1980.

Niskanen, Kirsti, Bosch, Mineke, and Wils, Kaat. "Scientific Personas in Theory and Practice: Ways of Creating Scientific, Scholarly, and Artistic Identities." Persona Studies 4, no. 1 (2018): 1-5.

Paul, Herman. "The Virtues and Vices of Albert Naudé: Toward a History of Scholarly Personae," History of Humanities 1 (2016): 327-338.

Paul, Herman. "The Virtues of a Good Historian in Early Imperial Germany: Georg Waitz's Contested Example.” Modern Intellectual History 15 (2018): 681-709.

Paul, Herman. "A Missing Link in the History of Historiography: Scholarly Personae in the World of Alfred Dove." History of European Ideas 45 (2019): 1011-1028.

Paul, Herman. "Introduction: Scholarly Personae: What They Are and Why They Matter" in How to Be a Historian: Scholarly Personae in Historical Studies, 1800-2000, edited by Herman Paul, 1-14. Manchester: Manchester University Press, 2019.

Paul, Herman. "Ranke vs Schlosser: Pairs of Personae in Nineteenth-Century German Historiography," in How to Be a Historian: Scholarly Personae in Historical Studies, 1800-2000, edited by Herman Paul, 36-52. Manchester: Manchester University Press, 2019.

Requate, Jörg. Journalismus als Beruf: Entstehung und Entwicklung des Journalistenberufs im 19. Jahrhundert: Deutschland im internationalen Vergleich. Göttingen: Vandenhoeck \& Ruprecht, 1995.

Schnicke, Falko. Die männliche Disziplin: Zur Vergeschlechtlichung der deutschen Geschichtswissenschaft 1780-1900. Göttingen: Wallstein, 2015.

Schnicke, Falko. "Princesses, Semen, and Separation: Masculinity and Body Politics in Nineteenth-Century German Historiography." German Historical Institute London Bulletin 40, no. 1 (2018): 26-60.

Smith, Bonnie G. The Gender of History: Men, Women, and Historical Practice. Cambridge, MA: Harvard University Press, 1998. 
Warland, Geneviève. "Der deutsch-jüdische Historiker Martin Philippson (1846 bis 1916): Wissenschaftsvermittler zwischen Deutschland und Belgien" in Belgica: terra incognita? Resultate und Perspektiven der historischen Belgienforschung, edited by Sebastian Bischoff et al., 56-67. Munster: Waxmann, 2016.

Weber, Max. The Methodology of the Social Sciences. Translated by Edward A. Shils and Henry A. Finch. New York: Free Press, 1949.

Wilke, Christiane. Forschen, Lehren, Aufbegehren: 100 Jahre akademische Bildung von Frauen in Bayern. Munich: Herbert Utz, 2003.

\footnotetext{
${ }^{1}$ Unless otherwise noted, all translations are my own. Funding has been generously provided by the Netherlands Organisation for Scientific Research (NWO).

${ }^{2}$ Martina Kessel, "The 'Whole Man': The Longing for a Masculine World in NineteenthCentury Germany," Gender and History 15 (2003): 1-31, at 2.

${ }^{3}$ Falko Schnicke, Die männliche Disziplin: Zur Vergeschlechtlichung der deutschen Geschichtswissenschaft 1780-1900 (Göttingen: Wallstein, 2015), 125.

${ }^{4}$ Ibid., 137.

${ }^{5}$ Herman Paul, “The Virtues of a Good Historian in Early Imperial Germany: Georg Waitz's Contested Example," Modern Intellectual History 15 (2018): 681-709.

${ }^{6}$ Herman Paul, "Introduction: Scholarly Personae: What They Are and Why They Matter," in How to Be a Historian: Scholarly Personae in Historical Studies, 1800-2000, ed. Herman Paul (Manchester: Manchester University Press, 2019), 1-14.

${ }^{7}$ In distinguishing between multiple modes of masculinity, this chapter draws on recent theorizing on 'multiple masculinities' as conveniently summarized in James W.

Messerschmidt, "Multiple Masculinities," in Handbook of the Sociology of Gender, ed. Barbara J. Risman, Carissa M. Froyum, and William J. Scarborough, 2nd ed. (Cham: Springer, 2018), 143-153 and Ben Griffin, "Hegemonic Masculinity as a Historical Problem," Gender and History 30 (2018): 377-400.

${ }^{8}$ As Heigel told the story in "Karl Theodor von Heigel," in Geistiges und künstlerisches München in Selbstbiographien, ed. W. Zils (Munich: Max Kellerer, 1913), 151-156. After his ennoblement in 1897, Heigel was entitled to add the prefix "von" to his last name.

${ }^{9}$ Alfred Dove, "Aus der Münchener historischen Werkstatt," Beilage zur Allgemeinen Zeitung (10 February 1900): 1-3, at 2.

${ }^{10}$ Erich König, "Karl Theodor von Heigel †," Historisches Jahrbuch 36 (1915), 476-479, at 477; E. Marcks, "Karl Theodor von Heigel," Jahrbuch der Königlich Bayerischen Akademie der Wissenschaften 1916 (Munich: Verlag der k. b. Akademie der Wissenschaften, 1916): 149-158, at 154.

${ }^{11}$ Kessel, “Whole Man,” 2; Karl Theodor von Heigel, "Friedrich von Ziegler” (1897), in Heigel, Biographische und kulturgeschichtliche Essays (Berlin: Allgemeiner Verein für deutsche Literatur, 1906), 290-297, at 290.

${ }^{12}$ Heigel, "Friedrich von Ziegler," 294; Karl Theodor Heigel, "Franz von Kobell” (1891), in Heigel, Essays aus neuerer Geschichte (Munich: C. C. Buchner, 1892), 326-347, at 327.

${ }^{13}$ Karl Theodor Heigel, "Wilhelm von Giesebrecht" (1889), in Heigel, Essays aus neuerer Geschichte (Munich: C. C. Buchner, 1892), 313-325, at 320, 321.

${ }^{14}$ Heigel, "Zur Erinnerung," 5; Heigel, "Friedrich von Ziegler," 293.

${ }^{15}$ Heigel, "Zur Erinnerung," 2.

${ }^{16}$ [Karl Theodor Heigel], "Ludwig von Buerkel," Allgemeine Zeitung (24 July 1903): 1-2, at 1.

${ }^{17}$ Schnicke, Männliche Disziplin, 121-128.
} 
${ }^{18}$ Karl Theodor von Heigel, "Die Verlegung der Ludwigs-Maximilians-Universität nach München im Jahre 1826" (1897), in Heigel, Neue geschichtliche Essays (Munich: C. H. Beck, 1902), 21-50, at 49.

${ }^{19}$ Karl Theodor von Heigel, "Festrede zum Gedächtnis Kaiser Wilhelm I" (1897), in Heigel, Neue geschichtliche Essays (Munich: C. H. Beck, 1902), 306-331, at 306; K. Th. von Heigel, Krieg und Wissenschaft: Rede gehalten in der öffentliche Sitzung der K. Akademie der Wissenschaften am 14. November 1914 (Munich: Verlag der K. B. Akademie der Wissenschaften, 1914), 10.

${ }^{20}$ Heigel, "Zur Erinnerung," 2.

${ }^{21}$ Ibid., 1, quoting Heinrich von Treitschke, Deutsche Geschichte im neunzehnten Jahrhundert, vol. 2 (Leipzig: S. Hirzel, 1882), 35.

${ }^{22}$ Heigel, "Zur Erinnerung," 2.

${ }^{23}$ Kessel, "Whole Man," 2.

${ }^{24}$ Heigel, "Zur Erinnerung," 3.

${ }^{25}$ Karl Theodor von Heigel, Zu Schillers Gedächtnis: Rede in der öffentlichen Sitzung der K. B. Akademie der Wissenschaften am 15. März 1905 (Munich: K. B Akademie der

Wissenschaften, 1905), 3, quoting [Johann Gottfried Herder], "Philosophie und Schwärmerei, zwo Schwestern," Der Teutsche Merkur (1776), no. 4, 138-149, at 147. The English translation is borrowed from Günther Jacoby, "Herder as Faust," The Open Court 27 (1913): 98-119, at 111.

${ }^{26}$ Heigel, "Wilhelm von Giesebrecht," 323.

${ }^{27}$ Jacob Burckhardt to Gottfried Kinkel, 17 April 1847, in Burckhardt, Briefe, ed. Max Burckhardt, vol. 3 (Basel: Benno Schwabe \& Co., 1955), 65-68, at 68. Treitschke himself had also dissociated himself from Zunftgelehrten, e.g. in a letter to Gustav Freytag, 13 November 1865, in Gustav Freytag und Heinrich von Treitschke im Briefwechsel, ed. Alfred Dove (Leipzig: S. Hirzel, 1900), 69-75, at 72.

${ }^{28}$ Johann Gustav Droysen to Wilhelm Arendt, 20 March 1857, in Droysen, Briefwechsel, ed. Rudolf Hübner, vol. 2 (Osnabrück: Biblio-Verlag, 1929), 441-443, at 442. The English translation is borrowed from Klaus Meister, "Thucydides in Nineteenth-Century Germany," in A Handbook to the Reception of Thucydides, ed. Christine Lee and Neville Morley (Chichester: Wiley-Blackwell, 2015), 197-217, at 211.

${ }^{29}$ Karl Hillebrand, "Ueber historisches Wissen und historischen Sinn" (1874), in Hillebrand, Zeiten, Völker und Menschen, vol. 2 (Berlin: Robert Oppenheim, 1875), 311-333, at 318.

${ }^{30}$ Heigel, "Zur Erinnerung," 3. Back in 1877, Heigel had dedicated his Habilitationsschrift to Ranke: Karl Theodor Heigel, Der österreichische Erbfolgestreit und die Kaiserwahl Karls VII. (Nördlingen: C. H. Beck, 1877), iii*.

${ }^{31}$ G. Waitz, Die historischen Übungen zu Göttingen: Glückwunschschreiben an Leopold von Ranke zum Tage der Feier seines fünfzigjährigen Doctorjubiläums, 20. Februar 1867 (Göttingen: W. Fr. Kästner, 1867), 4; Kasper Risbjerg Eskildsen, "Private Übungen und verkörpertes Wissen: Zur Unterrichtspraxis der Geschichtswissenschaft im neunzehnten Jahrhundert," in Akademische Wissenskulturen: Praktiken des Lehrens und Forschens vom Mittelalter bis zur Moderne, ed. Martin Kintzinger and Sita Steckel (Basel: Schwabe, 2015), 143-161.

${ }^{32}$ Georg Waitz, "Falsche Richtungen: Schreiben an den Herausgeber," Historische Zeitschrift 1 (1859): 17-28, at 25.

${ }^{33}$ Thomas Brechenmacher, "Wieviel Gegenwart verträgt historisches Urteilen? Die Kontroverse zwischen Heinrich von Sybel und Julius Ficker über die Bewertung der Kaiserpolitik des Mittelalters (1859-1862)," in Historische Debatten und Kontroversen im 19. und 20. Jahrhundert, ed. Jürgen Elvert and Susanne Krauß (Wiesbaden: Franz Steiner, 2003), 
34-54, esp. 53; Treitschke to Freytag, 13 November 1865, in Freytag und Treitschke im Briefwechsel, 72.

${ }^{34}$ Ernst Bernheim to Karl Lamprecht, 2 January 1885, in "Über das eigentliche Arbeitsgebiet der Geschichte”: Der Briefwechsel zwischen Karl Lamprecht und Ernst Bernheim sowie zwischen Karl Lamprecht und Henri Pirenne 1878-1915, ed. Luise Schorn-Schütte and Mircea Ogrin (Cologne: Böhlau, 2017), 66-67, at 67.

${ }^{35}$ Heigel, "Zur Erinnerung," 5, 1, 3.

${ }^{36}$ Karl Theodor Heigel, “An die akademische Jugend!” Süddeutsche Monatshefte 11 (1914): 776-779, at 779 .

${ }^{37}$ Heinrich von Treitschke to Alfred Dove, 1 September 1873, in Dove, Ausgewählte Briefe, ed. Oswald Dammann (Munich: F. Bruckmann, 1925), 38-39, at 39; Alfred Dove to Heinrich von Treitschke, 13 May 1873; ibid., 32-35, at 34.

${ }^{38}$ Heigel, "Zur Erinnerung," 1.

${ }^{39}$ Ibid., 2, under reference to Paul Bailleu, "Heinrich von Treitschke," Deutsche Rundschau 89 (1896): 41-76, 237-271, at 51.

${ }^{40}$ On the auxilliary sciences in Munich, see Hedwig Dickerhof-Fröhlich, Das historische Studium an der Universität München im 19. Jahrhundert: Vom Bildungsfach zum Berufsstudium (Munich: Minerva, 1979), 109-113.

${ }^{41}$ Max Jansen, Die Herzogsgewalt der Erzbischöfe von Köln in Westfalen seit dem Jahre 1180 bis zum Ausgange des 14. Jahrhunderts: Eine Verfassungsgeschichtliche Studie (Munich: H. Lüneburg, 1895); Maximilian Claar, Die Entwicklung der venetianischen Verfassung von der Einsetzung bis zur Schliessung des grossen Rates (1172-1297) (Munich: H. Lüneburg, 1895).

${ }^{42}$ Paul Joachimsohn, Gregor Heimburg (Bamberg: C. C. Buchner, 1891), viii; P. Albert, Matthias Döring, ein deutscher Minorit des 15. Jahrhunderts (Stuttgart: Süddeutsche Verlagsbuchhandlung, 1892), 129-194.

${ }^{43}$ Max Weber, The Methodology of the Social Sciences, trans. Edward A. Shils and Henry A. Finch (New York: Free Press, 1949), 90.

${ }^{44}$ On the rise of this virtue in the late nineteenth-century humanities, see Lorraine Daston, "Objectivity and Impartiality: Epistemic Virtues in the Humanities," in The Making of the Humanities, ed. Rens Bod, Jaap Maat, and Thijs Weststeijn, vol. 3 (Amsterdam: Amsterdam University Press, 2014), 27-41.

${ }^{45}$ Ernst Bernheim, Lehrbuch der historischen Methode: Mit Nachweis der wichtigsten Quellen und Hülfsmittel zum Studium der Geschichte (Leipzig: Duncker \& Humblot, 1889), 498, 493.

${ }^{46}$ Leopold Ranke, Englische Geschichte vornehmlich im sechszehnten und siebzehnten Jahrhundert, vol. 2 (Berlin: Duncker \& Humblot, 1860), 3; W. Wachsmuth, Entwurf einer Theorie der Geschichte (Halle: Hemmerde und Schwetschke, 1820), 126.

${ }^{47}$ Johann Gustav Droysen, Historik (1857), ed. Peter Leyh, vol. 1 (Stuttgart: FrommannHolzboog, 1977), 236; Johann Gustav Droysen to Georg Beseler, 16 January 1853, in Droysen, Briefwechsel, vol. 2, 144-146, at 145; Heinrich von Treitschke to Eduard Heinrich von Treitschke, 19 November 1864, in Heinrich von Treitschkes Briefe, ed. Max Cornicelius, vol. 2 (Leipzig: S. Hirzel, 1913), 351-352, at 351. On the sexual images that Droysen employed in describing the historian's work, see Schnicke, Männliche Disziplin, 422-435. ${ }^{48}$ Heigel, "Zur Erinnerung," 4, citing Heinrich von Treitschke to Karl Theodor Heigel, 2 February 1883 (published in Heinrich von Treitschkes Briefe, ed. Max Cornicelius, vol. 3 (Leipzig S. Hirzel, 1920), 548-549, at 549). Notably, this was an almost literal quotation from what the dramatist Heinrich von Kruse had put in the mouth of one of his characters, the imperial court official Granville: "I know that you treat as small what is small, as large what 
is large." Heinrich von Kruse, Moritz von Sachsen: Trauerspiel in fünf Aufzügen (Leipzig: S. Hirzel, 1872), 154.

${ }^{49}$ Heinrich von Treitschke, "F. C. Dahlmann," in Treitschke, Historische und politische Aufsätze vornehmlich zur neuesten deutschen Geschichte, 2nd ed. (Leipzig: S. Hirzel, 1865), 359-445, at 402.

${ }^{50}$ Heinrich von Treitschke, Deutsche Geschichte im neunzehnten Jahrhundert, vol. 1

(Leipzig: S. Hirzel, 1879), 28.

${ }^{51}$ Heigel, "Zur Erinnerung," 5.

${ }^{52}$ K. Th. Heigel, "Ludwig I. von Bayern als Freund der Geschichte: Zum Centenarium seines Geburtstags," Beilage zur Allgemeinen Zeitung (1886): 3449-3451, 3465-3467, at 3450;

Heigel, "Ueber die Memoiren des bayerischen Ministers Grafen von Montgelas,"

Sitzungsberichte der philosophisch-philologischen und historischen Klasse der k. b. Akademie der Wissenschaften zu München (1885): 424-442, at 425.

${ }^{53} \mathrm{~K}$. Th. Heigel, Deutsche Geschichte vom Tode Friedrich d. Gr. bis zur Auflösung des alten Reiches, vol. 1 (Stuttgart: J. G. Cotta, 1899), vii, viii. Back in 1838, Sybel had already stated that historians should write "cum ira et studio." Volker Dotterweich, Heinrich von Sybel: Geschichtswissenschaft in politischer Absicht (1817-1861) (Göttingen: Vandenhoeck \& Ruprecht, 1978), 42, 53.

${ }^{54}$ Heigel, Deutsche Geschichte, vol. 1, v.

${ }^{55}$ Lorraine Daston and H. Otto Sibum, "Introduction: Scientific Personae and Their Histories," Science in Context 16 (2003): 1-8.

${ }^{56}$ Dietrich Schäfer, Mein Leben (Berlin: K. F. Koehler, 1926), 89.

${ }^{57}$ Eberhard Gothein, "Bernhard Erdmannsdörffer †: Ein Gedenkwort," Preußische Jahrbücher 104 (1901): 15-22, at 20.

${ }^{58}$ Jeroen van Dongen and Herman Paul, "Introduction: Epistemic Virtues in the Sciences and the Humanities," in Epistemic Virtues in the Sciences and the Humanities, ed. Jeroen van Dongen and Herman Paul (Cham: Springer, 2017), 1-10.

${ }^{59}$ G. P. Gooch, History and Historians in the Nineteenth Century (London: Longmans, Green, and Co., 1913), 153; Thomas Gerhards, Heinrich von Treitschke: Wirkung und Wahrnehmung eines Historikers im 19. und 20. Jahrhundert (Paderborn: Ferdinand Schöningh, 2013), 75-84, 97, 137.

${ }^{60}$ Berlin-Brandenburg Academy of Sciences and Humanities, Max Lenz papers, inv. no. 8, "Geschichte der deutschen Geschichtschreibung" (1901), transcript by Martin Hass, 144-145; M. Philippson, "Henri de Treitschke," Revue Historique 61 (1896): 349-353, at 351. With this necrology, Philippson continued his long-standing feud with Sybel and Delbrück such as described by Geneviève Warland, "Der deutsch-jüdische Historiker Martin Philippson (1846 bis 1916): Wissenschaftsvermittler zwischen Deutschland und Belgien," in Belgica: terra incognita? Resultate und Perspektiven der historischen Belgienforschung, ed. Sebastian Bischoff et al. (Munster: Waxmann, 2016), 56-67, at 62. On Lenz's appropriation of Ranke, see Hans-Heinz Krill, Die Rankerenaissance: Max Lenz und Erich Marcks: Ein Beitrag zum historisch-politischen Denken in Deutschland, 1880-1935 (Berlin: Walter de Gruyter, 1962), 6-41 and, more critically, Günter Johannes Henz, Leopold von Ranke in Geschichtsdenken und Forschung, vol. 1 (Berlin: Duncker \& Humblot, 2014), 452-457.

${ }^{61}$ As I argue in Herman Paul, "The Virtues and Vices of Albert Naudé: Toward a History of Scholarly Personae," History of Humanities 1 (2016): 327-338.

${ }^{62}$ Kirsti Niskanen, Mineke Bosch, and Kaat Wils, "Scientific Personas in Theory and Practice: Ways of Creating Scientific, Scholarly, and Artistic Identities," Persona Studies 4, no. 1 (2018): 1-5; Mineke Bosch, "Scholarly Personae and Twentieth-Century Historians: Explorations of a Concept," Low Countries Historical Review 131, no. 4 (2016): 33-54; Mineke Bosch, "Persona and the Performance of Identity: Parallel Developments in the 
Biographical Historiography of Science and Gender, and the Related Uses of Self Narrative," L'Homme 24, no. 2 (2013): 11-22.

${ }^{63}$ Schnicke, Männliche Disziplin, 501-540; Falko Schnicke, "Princesses, Semen, and Separation: Masculinity and Body Politics in Nineteenth-Century German Historiography," German Historical Institute London Bulletin 40, no. 1 (2018): 26-60; Bonnie G. Smith, The Gender of History: Men, Women, and Historical Practice (Cambridge, MA: Harvard University Press, 1998), 103-129.

${ }^{64}$ [Paul Lindau], "Das literarische Parlament," Der Salon für Literatur, Kunst und Gesellschaft (1877): 226-230, at 227, as discussed in Herman Paul, "Ranke vs Schlosser: Pairs of Personae in Nineteenth-Century German Historiography," in Paul, How to Be a Historian, 36-52, at 41. Back in 1828, Heinrich Leo had already criticized Ranke's voice for being too female: Schnicke, Männliche Disziplin, 417-418.

${ }^{65}$ Angelika Epple, Empfindsame Geschichtsschreibung: Eine Geschlechtergeschichte der Historiographie zwischen Aufklärung und Historismus (Cologne: Böhlau, 2003).

${ }^{66}$ On the continuing power of this polar gender model in nineteenth-century Germany, see Karin Hausen, "Family and Role-Division: The Polarisation of Sexual Stereotypes in the Nineteenth Century: An Aspect of the Dissociation of Work and Family Life," in The German Family: Essays on the Social History of the Family in Nineteenth-and Twentieth-Century Germany, ed. Richard J. Evans and W. R. Lee (London: Croom Helm, 1981), 51-83, at 53-61. ${ }^{67}$ Heinrich von Treitschke, Politik: Vorlesungen gehalten an der Universität zu Berlin, ed. Max Cornicelius, vol. 1 (Leipzig: S. Hirzel, 1897), 247.

${ }^{68}$ Bernd Mütter, Die Geschichtswissenschaft in Münster zwischen Aufklärung und Historismus unter besonderer Berücksichtigung der historischen Disziplin an der Münsterschen Hochschule (Munster: Aschendorff, 1980), 246-251.

${ }^{69}$ Marcks, "Karl Theodor von Heigel," 156, 150.

${ }^{70}$ Ludwig Wolfram, “Zur Erinnerung an Karl Theodor von Heigel,” Deutsche Geschichtsblätter 16 (1915): 135-146, at 141; Gustav Sommerfeldt, "Der Geschichtsforscher Karl Theodor von Heigel," Mitteilungen des Vereines für Geschichte der Deutschen in Böhmen 54 (1915): 137-141, at 137; [Karl Alexander von Müller], "Karl Theodor von Heigel," Süddeutsche Monatshefte 12 (1915): 558-560, at 559; Paul Joachimsen, "Karl Theodor Heigel †," Vergangenheit und Gegenwart 5 (1915): 207; F[riedrich] D[üfel], "Karl Theodor von Heigel †," Westermanns Monatshefte 118 (1915): 425-426.

${ }^{71}$ Wilhelm Hausenstein, "Karl Theodor von Heigel," Das Forum 2 (1915): 44-48, at 44.

${ }^{72}$ Karl Theodor von Heigel, "Einheitsstaat oder Bundesstaat?" (1911), in Heigel, Deutsche Reden (Munich: C. H. Beck, 1916), 1-21, at 11-12.

${ }^{73}$ Christiane Wilke, Forschen, Lehren, Aufbegehren: 100 Jahre akademische Bildung von Frauen in Bayern (Munich: Herbert Utz, 2003), 33.

${ }^{74}$ Horst Walter Blanke, "Historiker als Beruf: Die Herausbildung des Karrieremusters 'Geschichtswissenschaftler' an den deutschen Universitäten von der Aufklärung bis zum klassischen Historismus," in Bildung, Staat, Gesellschaft im 19. Jahrhundert: Mobilisierung und Disziplinierung, ed. Karl-Ernst Jeismann (Stuttgart: Franz Steiner, 1989), 343-360; Jörg Requate, Journalismus als Beruf: Entstehung und Entwicklung des Journalistenberufs im 19. Jahrhundert: Deutschland im internationalen Vergleich (Göttingen: Vandenhoeck \& Ruprecht, 1995), 131-138, 222-236.

${ }^{75}$ Herman Paul, "A Missing Link in the History of Historiography: Scholarly Personae in the World of Alfred Dove," History of European Ideas 45 (2019): 1011-1028.

${ }^{76}$ Ivo Striedinger, "Karl Theodor Heigel," in Heigel, Deutsche Reden, ix-xx, at ix. 